\title{
Narrative Review of Subchondral Bone Morphology on Cartilage Damage (Osteoarthritis)
}

\author{
Nanda Yusril Mahendra ${ }^{1}$, Dicky Pratama Putra ${ }^{1}$, Imam Akbar ${ }^{1}$, Risky Utama Putra ${ }^{1}$, \\ Akbar Teguh Prakoso ${ }^{1}$, Muhammad Yanis ${ }^{1}$, Hendri Chandra ${ }^{1}$, Ardiyansyah \\ Syahrom ${ }^{2,3}$, Muhammad Imam Amrullah ${ }^{4}$, J. Jamari ${ }^{4}$, Hasan Basri ${ }^{1, *}$
}

${ }^{1}$ Department of Mechanical Engineering, Faculty of Engineering, Universitas Sriwijaya, Indralaya, Ogan Ilir, Indonesia.

${ }^{2}$ Applied Mechanics and Design, School of Mechanical Engineering, Faculty of Engineering, Universiti Teknologi Malaysia 81310 UTM Johor Bahru, Malaysia.

${ }^{3}$ Medical Devices and Technology Centre (MEDiTEC), Institute of Human Centred and Engineering (iHumEn), Universiti Teknologi Malaysia, 81310 UTM Johor Bahru, Malaysia.

${ }^{4}$ Department of Mechanical Engineering, Faculty of Engineering, Diponegoro University, Tembalang 50275, Central Java, Indonesia

*Corresponding author.Email: hasan_basri@unsri.ac.id

\begin{abstract}
The subchondral bone layer has an important role in supporting the articular cartilage under mechanical loads. Therefore, subchondral bone can affect cartilage damage, in this case osteoarthritis. Many studies have addressed osteoarthritis, but few studies have focused on the influence of subchondral bone morphology on the development of osteoarthritis. The purpose of this narrative review is to examine the relationship between subchondral bone morphology and the development of osteoarthritis by looking at the morphological differences between normal and osteoarthritis patients. The method used in the screening process for reputable journals, the author uses End-Note software. The keywords used are cartilage, osteoarthritis, subchondral bone, and morphology. Article search focused on pubmed database with several criteria. Then after getting the article, the data will be extracted into a table for further narrative review process. From the data obtained, it can be concluded that the morphological value in osteoarthritis patients is greater than normal patients, and patients suffering from osteoarthritis are infected more often in elderly patients. Other factors that can affect osteoarthritis are weight, height, and body mass index.
\end{abstract}

Keywords: Cartilage, osteoarthritis, subchondral bone, morphology

\section{INTRODUCTION}

Subchondral bone is found in huge joints like the knee and hip. Subchondral bone is a pile-supporting tissue that is separated into three sections consisting of a flexible portion, bone trabeculae, and a portion covered by marrow fat. The subchondral bone is located between the cartilage and the cancellous, so the influence of the subchondral bone will have a direct impact on the cartilage in the process of receiving loads and interacting with each other.

The subchondral bone layer acts very important as a support for the softer articular cartilage, this is because the subchondral bone layer distributes mechanical loads on all the layers of the joint surface with gradual transitions in stress and strain [1]. Although the biomechanically connected subchondral bone and articular cartilage are well formed, there is a question as to whether there is biochemical communication between them. When there is a change in the pattern of joint loading, such as in osteoarthritis (OA), there is an increase which is indicated by subchondral bone in the form of morphological can make cyst formation, sclerosis and increasing osteophytes [2-6]. The cause of these changes are cytokines release and the subchondral bone factors of growthing during the remodeling period which are easly move to the articular cartilage. It is 
known that this will trigger the occurrence of osteoarthritis and produce negative feedback and positive cycle which are ultimately supports the development of osteoarthritis [7-8].

Articular cartilage and subchondral bone degeneration process is related to several triggering factors, such as morphological processes and load distribution processes $[9,10]$. Term of composition, structure, and mechanical properties can changes because of this factors [11-14].

In several previous studies that have been carried out, these studies have only focused on looking at changes that occur in cartilage in osteoarthritis disease but do not relate them to subchondral bone. Even though we know that subchondral bone and cartilage are located in one layer, namely osteochandral, with the same function, namely receiving the load distribution process. Therefore, in this study the authors will look for the relationship between cartilage and subchondral bone through mainly subchondral bone morphology by classifying data from previous studies through a narrative review method by comparing subchondral bone morphology data in normal patients and osteoarthritis patients. This review aimed to investigate whether the literature supports the hypothesis that differences in subchondral bone morphology may influence the development of osteoarthritis.

\section{METHOD}

\subsection{Systematic literature search}

In the literature search process, the author uses EndNote software. This software was chosen because the use in the search process and the journal is easy to understand, and the results from the journal screening process can meet the criteria desired by the author. The search only focused on PubMed libraries and was limited to 2000 to 2021. After that, the search was limited to using keywords, titles and abstracts. The keywords used are cartilage, osteoarthritis, subchondral bone, and morphology. The search for journals is focused on English-language journals because they want to cover a broader scope.

\subsection{Eligibility Criteria}

In the process of this stage of the study, the authors review each design study with the main criteria, namely the paper containing subchondral bone, cartilage, subchondral bone morphology.

\subsection{Study Selection}

The search for papers using the systematic review method was carried out on the PubMed database. A complete description of the search result data used is stored in the EndNote software database by creating smart groups. In order not to widen the focus of the search, the strategy is set in the search in the PubMed database. This study uses inclusion and exclusion criteria, with the results of screening titles and abstracts of 143 articles. then the articles were filtered again, so the results obtained were 35 articles. Articles were evaluated against the full text to identify studies that met the inclusion and exclusion criteria. Relevant articles obtained as many as 11 articles. Articles will be entered into the table for a narrative review process.

\subsection{Inclusion Criteria}

Studies were included if they met the following criteria: studies related to the main research focus; only in English articles; and this study uses data on the morphology of the subchondral bone and related factors regarding the development of osteoarthritis.

\subsection{Data Extraction}

Based on the inclusion criteria, the authors independently examined all articles, and the reference lists of all relevant articles were also screened to identify other potential data sources. then the data will be entered into a table for the review process, as shown in tables 1 and 2.

\section{DISCUSSION}

Bone morphology and the impact of cartilage disruption have been widely studied by researchers, in this study osteoarthritis became the focus of cartilage disorders. However, from the few studies that have been conducted, very few link the development the osteoarthritis in the subchondral bone in normal and when subchondral bone infectued by osteoarthritis. Meanwhile, it should be notable to draw conclusions about factors that influence the development of osteoarthritis and subchondral bone morphology. Therefore, this paper is purpose to know at the morphological characteristics that are specific to the subchondral bone in patients with osteoarthritis.

In term of morphology, for example, in the superficial zone of the articular cartilage, fibrillation will occur and cartilage deformities occur with age [15-17]. Age factor affects articular cartilage thickness [19]. Subchondral bone based on its structure consists of two different anatomy, namely the subchondral bone layer and the subchondral trabecular bone layer [20,21]. With age, the subchondral bone layer (density and thickness) will continue to increase. While trabecular thickness (Tb.Th) of ST and the bone volume (BV/TV), the thickness of the subchondral bone layer and the thickness of the articular cartilage has an opposite connection, but the subchondral bone porosity has a positive correlation [21].

Regarding mechanical properties and tensile strength, the modulus of elasticity of articular cartilage will decrease significantly with increasing age (22-24)The process by which the body converts mechanical stimuli during joint movement can lead to bone modelling that the microstructure subchondral bone modifies, which stiffens with ageing. This effect is connecting with increased mass and density and a reduction in bone porosity $[25,26]$. 
Loss of progressive structure and articular cartilage function in developing osteoarthritis is due to a disequilibrium in the cartilage tissue between anabolic and catabolic processes. Based on bone metabolism trials, healthy patients have lower bone density (BMD) or bone mineral content (BMC) than patients with osteoarthritis [27]. However, it does not mean that the mechanical properties of bone in OA patients are increased [28]. It shows that in the early stages of development of osteoarthritis, the subchondral bone experienced a significant thickening process in the subchondral bone but experienced a decrease in mechanical properties compared to the normal bone so that the morphological structure should be reviewed from a research and know its correlation to the mechanical ability of the subchondral bone to osteoporosis [29].

Many methods are used to view the parameters contained in the subchondral bone structure, and the most popular is the CT scan. This method is widely used because the process is not too complicated, and the scanning process is entirely accurate. Therefore, the authors choose this method in collecting data in previous studies so that later the authors will choose this method for future research.
CT scan is an examination method by using an X-ray source to examine the object and enlarging the projection of the image to be viewed. Then the image will be transferred to the computer according to the object's view and angle of rotation. The trabecular thickness (Tb.Th), trabecular separation (Tb.Sp), trabecular number (Tb.N) and volume (BV/TV) of the bone are the data will be obtained in this process. this method has the advantage because this method is quite fast, has the accuracy of the data generated and does not damage the object being scanned. However, this method also has a weakness; namely, the process involves relatively high radiation produced by $\mathrm{x}$-rays Behind the advantages, this method has disadvantages such as high radiation from X-rays generated during the process. This method is aimed at in vitro analysis of excised bone, but this methode is quite difficult for living patients to analyze the structure of the trabecular bone. However, for clinical imaging technology, it is very beneficially, because it make the structure of subchondral bone analysis maybe has been investigated. With CT, multi-line detectors, resolution of the image and structural analysis of trabecular meshwork in osteoporosis patients are increasing [30].

From Tables 1 and 2, the following are the results of the review process that has been carried out.

Table 1. Subchondral bone morphology data for normal patients

\begin{tabular}{|c|c|c|c|c|c|c|c|c|c|c|c|}
\hline \multirow[b]{2}{*}{ No } & \multirow[b]{2}{*}{ Title } & \multirow{2}{*}{$\begin{array}{l}\text { Author } \\
\text { (Year) }\end{array}$} & \multicolumn{4}{|c|}{ Morphology } & \multirow[b]{2}{*}{ Gender } & \multirow{2}{*}{$\begin{array}{c}\text { BMI } \\
\left(\mathbf{k g} / \mathrm{m}^{2}\right)\end{array}$} & \multirow{2}{*}{$\begin{array}{c}\text { Age } \\
\text { (years) }\end{array}$} & \multirow{2}{*}{$\begin{array}{c}\text { Height } \\
\text { (m) }\end{array}$} & \multirow{2}{*}{$\begin{array}{c}\text { Weight } \\
\text { (kg) }\end{array}$} \\
\hline & & & $\begin{array}{c}\text { BV/TV } \\
(\%)\end{array}$ & $\begin{array}{l}\text { Tb.N } \\
(\mathbf{m m})\end{array}$ & $\begin{array}{l}\text { Tb.Th } \\
(\mathbf{m m})\end{array}$ & $\begin{array}{l}\text { Tb.Sp } \\
(\mathbf{m m})\end{array}$ & & & & & \\
\hline 1 & $\begin{array}{l}\text { Differences in } \\
\text { subchondral } \\
\text { trabecular bone } \\
\text { microstructure and } \\
\text { finite element } \\
\text { analysis-based } \\
\text { biomechanical } \\
\text { properties between } \\
\text { osteoporosis and } \\
\text { osteoarthritis }\end{array}$ & $\begin{array}{l}\text { Zihao He } \\
\text { (2020) }\end{array}$ & $\begin{array}{c}22,64 \pm \\
5,07\end{array}$ & $\begin{array}{c}1,53 \pm \\
0,29\end{array}$ & $\begin{array}{c}0,19 \pm \\
0,03\end{array}$ & $\begin{array}{c}0,68 \pm \\
0,1\end{array}$ & $\begin{array}{c}\text { Female } \\
(4) / \\
\text { Male(4) }\end{array}$ & $\begin{array}{c}24,13 \pm \\
2,37\end{array}$ & $\begin{array}{c}65,25 \pm \\
23,3\end{array}$ & $\begin{array}{l}164,63 \\
\pm 6,76\end{array}$ & $\begin{array}{c}65,13 \pm \\
3,83\end{array}$ \\
\hline 2 & $\begin{array}{l}\text { Changes in } \\
\text { articular cartilage } \\
\text { and subchondral } \\
\text { bone } \\
\text { histomorphometry } \\
\text { in osteoarthritic } \\
\text { knee joints in } \\
\text { humans } \\
\end{array}$ & $\begin{array}{c}\text { Dragica } \\
(2002)\end{array}$ & $\begin{array}{c}37,8 \pm \\
8,1\end{array}$ & $\begin{array}{c}2,3 \pm \\
0,4\end{array}$ & $\begin{array}{c}0,17 \pm \\
18,2\end{array}$ & $\begin{array}{c}0,35 \pm \\
0,05\end{array}$ & $\begin{array}{c}\text { Female } \\
(7) / \\
\text { Male(3) }\end{array}$ & & 47,5 & & \\
\hline 3 & $\begin{array}{l}\text { Accumulation } \\
\text { of microdamage } \\
\text { in subchondral } \\
\text { bone } \\
\text { at the femoral } \\
\text { head in patients } \\
\text { with end-stage } \\
\text { osteoarthritis } \\
\text { of the hip }\end{array}$ & $\begin{array}{c}\text { Masashi S } \\
\text { himamura } \\
(2019)\end{array}$ & $\begin{array}{c}21,8 \pm \\
4,8\end{array}$ & $\begin{array}{c}1,0 \pm \\
0,3\end{array}$ & $\begin{array}{c}0,25 \pm \\
0,016\end{array}$ & $\begin{array}{c}0,58 \pm \\
0,03\end{array}$ & $\begin{array}{c}\text { Female } \\
(5) / \\
\text { Male(4) }\end{array}$ & & 83,1 & & \\
\hline \multirow[t]{2}{*}{4} & \multirow{2}{*}{$\begin{array}{l}\text { Influence of } \\
\text { meniscus on } \\
\text { cartilage and } \\
\text { subchondral bone } \\
\text { features of knees } \\
\text { from older } \\
\text { individuals: A } \\
\text { cadaver study }\end{array}$} & \multirow{2}{*}{$\begin{array}{c}\text { Se'bastien } \\
\text { Touraine } \\
\text { (2017) }\end{array}$} & $\begin{array}{c}20,2 \pm \\
7,4\end{array}$ & $\begin{array}{c}1,4 \pm \\
0,3\end{array}$ & $\begin{array}{c}0,14 \pm \\
0,02\end{array}$ & $\begin{array}{c}0,48 \pm \\
0,09\end{array}$ & $\begin{array}{c}\text { Female } \\
\text { (18) }\end{array}$ & & $\begin{array}{c}85,7 \pm \\
7,5\end{array}$ & & \\
\hline & & & $28,3 \pm$ & $\begin{array}{c}1,5 \pm \\
0,2\end{array}$ & $\begin{array}{c}0,18 \pm \\
0,03\end{array}$ & $\begin{array}{c}0,49 \pm \\
0,05\end{array}$ & $\begin{array}{c}\text { Male } \\
(10)\end{array}$ & & $\begin{array}{c}77,9 \pm \\
12,0\end{array}$ & & \\
\hline
\end{tabular}


Table 2. Subchondral bone morphology data for osteoarthritis patients

\begin{tabular}{|c|c|c|c|c|c|c|c|c|c|c|c|}
\hline \multirow[b]{2}{*}{ No } & \multirow[b]{2}{*}{ Title } & \multirow{2}{*}{$\begin{array}{l}\text { Author } \\
\text { (Year) }\end{array}$} & \multicolumn{4}{|c|}{ Morphology } & \multirow[b]{2}{*}{ Gender } & \multirow{2}{*}{$\begin{array}{c}\text { BMI } \\
\left(\mathrm{kg} / \mathrm{m}^{2}\right)\end{array}$} & \multirow{2}{*}{$\begin{array}{c}\text { Age } \\
\text { (years) }\end{array}$} & \multirow{2}{*}{$\begin{array}{c}\text { Height } \\
\text { (m) }\end{array}$} & \multirow{2}{*}{$\begin{array}{c}\text { Weight } \\
\text { (kg) }\end{array}$} \\
\hline & & & $\begin{array}{c}\text { BV/TV } \\
(\%)\end{array}$ & $\begin{array}{l}\text { Tb.N } \\
(\mathbf{m m})\end{array}$ & $\begin{array}{l}\text { Tb.Th } \\
(\mathbf{m m})\end{array}$ & $\begin{array}{l}\text { Tb.Sp } \\
(\mathbf{m m})\end{array}$ & & & & & \\
\hline 1 & $\begin{array}{l}\text { Differences in } \\
\text { subchondral } \\
\text { trabecular bone } \\
\text { microstructure and } \\
\text { finite element } \\
\text { analysis-based } \\
\text { biomechanical } \\
\text { properties between } \\
\text { osteoporosis and } \\
\text { osteoarthritis }\end{array}$ & $\begin{array}{c}\text { Zihao He } \\
(2020)\end{array}$ & $\begin{array}{c}29,85 \pm \\
13,37\end{array}$ & $\begin{array}{c}2,47 \pm \\
1,08\end{array}$ & $\begin{array}{c}0,19 \pm \\
0.03\end{array}$ & $\begin{array}{c}0,53 \pm \\
0,27\end{array}$ & $\begin{array}{l}\text { Female } \\
(10) / \\
\text { Male(3) }\end{array}$ & $\begin{array}{c}23,35 \pm \\
2,53\end{array}$ & $\begin{array}{c}52,31 \pm \\
13,39\end{array}$ & $\begin{array}{c}1,63 \pm \\
7,57\end{array}$ & $\begin{array}{c}63,23 \pm \\
11,1\end{array}$ \\
\hline 2 & $\begin{array}{l}\text { Microstructural } \\
\text { alterations of } \\
\text { femoral head } \\
\text { articular cartilage } \\
\text { and subchondral } \\
\text { bone in } \\
\text { osteoarthritis and } \\
\text { osteoporosis }\end{array}$ & $\begin{array}{c}\text { D. } \\
\text { Bobinac } \\
(2013)\end{array}$ & $\begin{array}{c}18,2 \pm \\
18,1\end{array}$ & $\begin{array}{c}1,09 \pm \\
0,37\end{array}$ & $\begin{array}{c}0,16 \pm \\
0,03\end{array}$ & $\begin{array}{c}0,64 \pm \\
0,13\end{array}$ & - & - & $62 \pm 12$ & & \\
\hline 3 & $\begin{array}{l}\text { Osteoporotic } \\
\text { changes of } \\
\text { subchondral } \\
\text { trabecular bone in } \\
\text { osteoarthritis of the } \\
\text { knee: a 3-T MRI } \\
\text { study }\end{array}$ & $\begin{array}{l}\text { K. Chiba } \\
\text { (2012) }\end{array}$ & $\begin{array}{c}28,9 \pm \\
10,7\end{array}$ & $\begin{array}{c}0,53 \pm \\
0,11\end{array}$ & $\begin{array}{c}0,52 \pm \\
0,09\end{array}$ & $\begin{array}{c}1,42 \pm \\
18,1\end{array}$ & & $23,4 \pm 6,3$ & $\begin{array}{c}68,1 \pm \\
7,5\end{array}$ & $\begin{array}{c}1,52 \pm \\
4,7\end{array}$ & $\begin{array}{c}54,3 \pm \\
14,9\end{array}$ \\
\hline 4 & $\begin{array}{l}\text { Changes in articular } \\
\text { cartilage and } \\
\text { subchondral bone } \\
\text { histomorphometry } \\
\text { in osteoarthritic } \\
\text { knee joints in } \\
\text { humans }\end{array}$ & $\begin{array}{c}\text { Dragica } \\
\text { Bobinac } \\
(2003)\end{array}$ & $\begin{array}{c}54,1 \pm \\
10,6\end{array}$ & $\begin{array}{c}2,1 \pm \\
0,4\end{array}$ & $\begin{array}{c}0,33 \pm \\
0,02\end{array}$ & $\begin{array}{c}0,29 \pm \\
0,05\end{array}$ & $\begin{array}{c}\text { Female } \\
(7) / \\
\text { Male(3) }\end{array}$ & & 62,5 & & \\
\hline 5 & $\begin{array}{l}\text { Micro-CT and } \\
\text { mechanical } \\
\text { evaluation of } \\
\text { subchondral } \\
\text { trabecular bone } \\
\text { structure between } \\
\text { postmenopausal } \\
\text { women with } \\
\text { osteoarthritis and } \\
\text { osteoporosis } \\
\end{array}$ & $\begin{array}{l}\text { Z.-M. } \\
\text { Zhang } \\
(2010)\end{array}$ & $\begin{array}{c}34,83 \pm \\
11,5\end{array}$ & $\begin{array}{c}1,54 \pm \\
0,26\end{array}$ & $\begin{array}{c}0,25 \pm \\
0.05\end{array}$ & $\begin{array}{c}0,58 \pm \\
0,10\end{array}$ & & & 75 & & \\
\hline 6 & $\begin{array}{l}\text { Relationship } \\
\text { Between } \\
\text { Microstructure and } \\
\text { Degree of } \\
\text { Mineralization in } \\
\text { Subchondral Bone } \\
\text { of Osteoarthritis: A } \\
\text { Synchrotron } \\
\text { Radiation mCT } \\
\text { study }\end{array}$ & $\begin{array}{l}\text { Ko } \\
\text { Chiba } \\
\text { (2012) }\end{array}$ & $55,6 \pm$ & $1,08 \pm$ & $\begin{array}{c}0,23 \pm \\
0,01\end{array}$ & 0,26 & $\begin{array}{c}\text { Female } \\
(10)\end{array}$ & & $72 \pm 5$ & & \\
\hline 7 & $\begin{array}{l}\text { Subchondral bone } \\
\text { micro-architectural } \\
\text { alterations in } \\
\text { osteoarthritis: a } \\
\text { synchrotron micro- } \\
\text { computed } \\
\text { tomography study }\end{array}$ & $\begin{array}{l}\text { Dr. C. } \\
\text { Chappar } \\
\text { d Ph.D } \\
(2006)\end{array}$ & $\begin{array}{c}35,9 \pm \\
7,0\end{array}$ & $\begin{array}{c}2,30 \pm \\
0,33\end{array}$ & $\begin{array}{c}0,23 \pm \\
0,04\end{array}$ & $\begin{array}{c}0,28 \pm \\
0,06\end{array}$ & & & $\begin{array}{c}79,1 \pm \\
13,0\end{array}$ & & \\
\hline 8 & $\begin{array}{l}\text { Accumulation } \\
\text { of microdamage } \\
\text { in subchondral bone } \\
\text { at the femoral head } \\
\text { in patients } \\
\text { with end-stage } \\
\text { osteoarthritis } \\
\text { of the hip }\end{array}$ & $\begin{array}{c}\text { Masashi } \\
\text { Shimam } \\
\text { ura } \\
(2019)\end{array}$ & $\begin{array}{c}41,3 \pm \\
11,5\end{array}$ & $\begin{array}{c}1,4 \pm \\
0,5\end{array}$ & $\begin{array}{c}0,31 \pm \\
0,1\end{array}$ & $\begin{array}{c}0,48 \pm \\
0,20\end{array}$ & $\begin{array}{c}\text { Female } \\
(10)\end{array}$ & & 73,7 & & \\
\hline
\end{tabular}




\section{CONCLUSION}

The most important factor to analyzing the characterization of subchondral bone in order to predict its quality is morphology. By and large, morphology influences the improvement of osteoarthritis and the mechanical properties of subchondral bone. The data generated from a previous narrative review of the connection between morphology of subchondral bone to damage of cartilage are useful for predicting the development of osteoarthritis in patients. It was found that the morphology in normal patients was smaller than in patients with osteoarthritis. It indicates that many patients have osteoarthritis. In addition, there are also the majority of patients suffering from infected osteoarthritis occur in elderly patients. Other factors that influence osteoarthritis are weight, height and BMI of the patient. Therefore, in the future, it is necessary to conduct further research in order to accelerate the diagnosis and obtain the best way to treat the development of osteoarthritis in patient.

\section{ACKNOWLEDGMENTS}

The research publication of this article was funded by DIPA of Public Service Agency of Universitas Sriwijaya 2021. In accordance with the Rector's Decree Number: 0014/UN9/SK.LP2M.PT/2021, On May 25, 2021. We gratefully thank the Mechanical Engineering Department, Faculty of Engineering, Universitas Sriwijaya for their strong support of this study, along with the Medical Device and Technology Center (MEDITEC), Institute of Human-Centered and Engineering (iHumEn), Universiti Teknologi Malaysia.

\section{REFERENCES}

1. Mente PL, Lewis JL. 1994. Elastic-Modulus of calcified cartilage is an order of magnitude less than that of subchondral bone. J Orthop Res 12:637-647.

2. Radin EL, Martin RB, Burr DB, et al. 1984. Effects of mechanical loading on the tissues of the rabbit knee. $\mathbf{J}$ Orthop Res 2:221-234.

3. Dequeker J, Mokassa L, Aerssens J, et al. 1997. Bone density and local growth factors in generalized osteoarthritis. Microsc Res Tech 37:358-371.

4. Burr DB. 2004. Anatomy and physiology of the mineralized tissues: role in the pathogenesis of osteoarthrosis. Osteoarth Cart 12(Suppl A):S20-30.

5. Aspden RM. 2008. Osteoarthritis: a problem of growth not decay? Rheumatology (Oxford) 47:14521460.

6. Li B, Aspden RM. 1997. Mechanical and material properties of the subchondral bone plate from the femoral head of patients with osteoarthritis or osteoporosis. Ann Rheum Dis 56:247- 254
7. Westacott CI, Webb GR, Warnock MG, et al. 1997. Alteration of cartilage metabolism by cells from osteoarthritic bone. Arthritis Rheum 40:1282-1291.

8. Lajeunesse D, Reboul P. 2003. Subchondral bone in osteoarthritis: a biologic link with articular cartilage leading to abnormal remodeling. Curr Opin Rheumatol 15:628-633.

9. Lotz M, Loeser RF (2012) Effects of aging on articular cartilage homeostasis. Bone 51, 241-248.

10. Loeser RF (2009) Aging and osteoarthritis: the role of chondrocyte senescence and aging changes in the cartilage matrix. Osteoarthr Cartilage 17, 971-979.

11. Stolz M, Gottardi R, Raiteri R, et al. (2009) Early detection of aging cartilage and osteoarthritis in mice and patient samples using atomic force microscopy. Nat Nanotechnol 4, 186-192.

12. Temple MM, Bae WC, Chen MQ, et al. (2009) Biomechanical, structural, and biochemical indices of degenerative and osteoarthritic deterioration of adult human articular cartilage of the femoral condyle. Osteoarthritis Cartilage 17, 1469-1476.

13. Lories RJ, Luyten FP (2011) The bone-cartilage unit in osteoarthritis. Nat Rev Rheumatol 7, 43-49.

14. Li XF, Cai XR, Fan F, et al. (2015b) Observation of sGAG content of human hip joint cartilage in different old age groups based on EPIC micro-CT. Connective Tissue Res 56, 99-105.

15. Armstrong CG, Mow VC (1982) Variations in the intrinsic mechanical properties of human articular cartilage with age, degeneration, and water content. J Bone Joint Surg 64, 88-94.

16. Hollander AP, Pidoux I, Reiner A, et al. (1995) Damage to type II collagen in aging and osteoarthritis starts at the articular surface, originates around chondrocytes, and extends into the cartilage with progressive degeneration. J Clin Invest 96, 2859-2869.

17. Bae WC, Temple MM, Amiel D, et al. (2003) Indentation testing of human cartilage: sensitivity to articular surface degeneration. Arthritis Rheum 48, 3382-3394.

18. Bae WC, Temple MM, Amiel D, et al. (2003) Indentation testing of human cartilage: sensitivity to articular surface degeneration. Arthritis Rheum 48, 3382-3394.

19. Ding M, Odgaard A, Linde F, et al. (2002) Age-related variations in the microstructure of human tibial cancellous bone. J Orthop Res 20, 615-621.

20. Li G, Yin J, Gao J, et al. (2013) Subchondral bone in osteoarthritis: insight into risk factors and microstructural changes. Arthritis Res Ther 15, 223.

21. Hamann N, Zaucke F, Dayakli M, et al. (2013) Growth-related structural, biochemical, and mechanical properties of the functional bone-cartilage unit. J Anat 222, 248-259. 
22. Guo BY, Liao DH, Li XY, et al. (2007) Age and gender related changes in biomechanical properties of healthy human costal cartilage. Clin Biomech 22, 292-297.

23. Lau A, Oyen ML, Kent RW, et al. (2008) Indentation stiffness of aging human costal cartilage. Acta Biomater 4, 97-103.

24. Moriyama H, Kanemura N, Brouns I, et al. (2012) Effects of aging and exercise training on the histological and mechanical properties of articular structures in knee joints of male rat. Biogerontology 13, 369-381.

25. Ding M (2010) Microarchitectural adaptations in aging and osteoarthrotic subchondral bone issues. Acta Orthop 81, 1-53.

26. Wang T, Wen CY, Yan CH, et al. (2013) Spatial and temporal changes of subchondral bone proceed to microscopic articular cartilage degeneration in guinea pigs with spontaneous osteoarthritis. Osteoarthr Cartilage 21, 574-581.

27. Jiang LS, Zhang ZM, Jiang SD, Chen WH, Dai LY (2008) Differential bone metabolism between postmenopausal women with osteoarthritis and osteoporosis. J Bone Miner Res 23:475-483

28. Ding M, Odgaard A, Hvid I (2003) Changes in the threedimensional microstructure of human tibial cancellous bone in early osteoarthritis. J Bone Jt Surg Br 85:906-912.

29. Ding M, Odgaard A, Linde F, Hvid I (2002) Agerelated variations in the microstructure of human tibia cancellous bone. J Orthop Res 20:615-621

30. Ito M, Ikeda K, Nishiguchi M, Shindo H, Uetani M, Hosoi T dkk (2005) Multi-detektor baris CT pencitraan struktur mikro tulang belakang untuk evaluasi risiko patah tulang. J Bone Miner Res 20:1828-1836 